Review

\title{
Crucial Role of Extracellular Vesicles in Bronchial Asthma
}

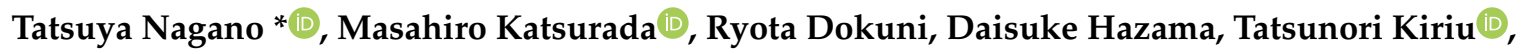 \\ Kanoko Umezawa, Kazuyuki Kobayashi and Yoshihiro Nishimura
}

Division of Respiratory Medicine, Department of Internal Medicine, Kobe University Graduate School of Medicine, 7-5-1 Kusunoki-cho, Chuo-ku, Kobe 650-0017, Japan; mskatsu@med.kobe-u.ac.jp (M.K.); rdokuni@med.kobe-u.ac.jp (R.D.); dhazama@med.kobe-u.ac.jp (D.H.); tkiriu@med.kobe-u.ac.jp (T.K.); kanoko03@med.kobe-u.ac.jp (K.U.); kkoba@med.kobe-u.ac.jp (K.K.); nishiy@med.kobe-u.ac.jp (Y.N.)

* Correspondence: tnagano@med.kobe-u.ac.jp; Tel.: +81-78-382-5660

Received: 2 May 2019; Accepted: 25 May 2019; Published: 27 May 2019

\begin{abstract}
Extracellular vesicles (EVs) are circulating vesicles secreted by various cell types. EVs are classified into three groups according to size, structural components, and generation process of vesicles: exosomes, microvesicles, and apoptotic bodies. Recently, EVs have been considered to be crucial for cell-to-cell communications and homeostasis because they contain intracellular proteins and nucleic acids. Epithelial cells from mice suffering from bronchial asthma (BA) secrete more EVs and suppress inflammation-induced EV production. Moreover, microarray analyses of bronchoalveolar lavage fluid have revealed that several microRNAs are useful novel biomarkers of BA. Mesenchymal stromal cell-derived EVs are possible candidates of novel BA therapy. In this review, we highlight the biologic roles of EVs in BA and review novel EV-targeted therapy to help understanding by clinicians and biologists.
\end{abstract}

Keywords: extracellular vesicles; exosomes; microparticles; apoptotic bodies

\section{Introduction}

Extracellular vesicles (EVs) were first described as "platelet products" in human plasma in 1967 [1]. EVs were discovered to be associated with intercellular transport of trophic substances or nutrients in 1980 [2]. EVs have been called different names in different reports: "exosomes", "microvesicles", "ectosomes", "oncosomes", and "cytoplasts" [3]. György et al. classified EVs into exosomes, microvesicles, and apoptotic bodies according to size, structural components, and generation process of vesicles [4].

The basic features of exosomes, microvesicles, and apoptotic bodies have been covered recently in numerous review articles [4]. Briefly, exosomes are vesicles surrounded by a phospholipid bilayer and are approximately $50-100 \mathrm{~nm}$ in diameter. Exosomes are generated by exocytosis of multivesicular bodies from immune cells and tumor cells [5]. Exosomes have essential roles in normal cellular function and homeostatic regulation of the host tissues and organs [6-12]. Exosomes can be isolated from bodily fluids including blood [13], urine [14], semen [6], breast milk [15], and bronchoalveolar lavage fluid (BALF) [16]. Microvesicles are also surrounded by a phospholipid bilayer and are 100-1000 nm in diameter [17]. Microvesicles are generated by regulated release due to budding/blebbing of the plasma membranes of platelets, red blood cells, and endothelial cells [18]. Apoptotic bodies are 1-5 $\mu \mathrm{m}$ in diameter and released as blebs of cells undergoing apoptosis [19]. Apoptotic bodies are also surrounded by a phospholipid bilayer. The International Society for Extracellular Vesicles (http://www.isev.org) also recommends use of the term "EVs". Therefore, in this review, we use "EVs" to avoid confusion or ambiguity. 
EVs contain intracellular proteins (receptors, transcription factors, enzymes, extracellular-matrix proteins) and nucleic acids including DNA, messenger RNA (mRNA), microRNA (miRNA), and noncoding RNA. They serve as mediators of intercellular communication and have a crucial role in cell-to-cell communications and homeostasis [20,21]. EVs have been extensively studied and reported to be associated with a wide range of inflammatory diseases [22-24] and respiratory diseases [25-28]. Hence, EVs have received considerable attention as novel biomarkers and therapeutic targets. Indeed, it has been reported that intranasal administration of EVs in BALF collected from experimental mice suffering from pollinosis induces immune tolerance and suppresses allergic reactions [29]. In an experimental model of bronchial asthma (BA) in mice, EVs were secreted from epithelial cells and suppressed production of inflammation-induced EVs [30]. This result suggested that EVs are useful for BA treatment. Moreover, by using microarray analyses of BALF, 16 miRNAs containing let-7 and miRNA-200 seem to be useful as novel biomarkers of BA [31]. Although the biological functions of EVs and their association with disease are not fully elucidated, EVs are thought to have a role in cellular homeostasis through the autophagy pathways in a complex intercellular and systemic messaging system [11,32]. In this review, we summarize recent findings of EV-mediated BA pathogenesis and discuss the potential clinical usefulness of EVs as biomarkers and therapeutic agents for BA.

\section{EVs in BA Pathogenesis}

\subsection{EV-Secreting Cells in the Respiratory System}

EV-secreting cells are summarized in Table 1. In the respiratory system, EVs are secreted from bronchial epithelial cells (BECs), alveolar macrophages, vascular endothelial cells, and fibroblasts [30]. In particular, BECs are considered to be major sources of pulmonary EVs [30]. Environmental stimuli such as cigarette smoke induce BEC injury and induce release of proinflammatory cytokines and chemokines from injured BECs [33]. Human epithelial cell lines, BEAS-2B, secrete full-length CCN1, the first member of the CCN protein family, and facilitate the interleukin (IL)-8 and vascular endothelial growth factor (VEGF) release in response to cigarette smoke extract (CSE) [34]. In addition, BECs secrete various sizes of EVs which contain different membrane-tethered mucins [35,36]. BEC-derived mucins including mucin (MUC)-1, MUC-4, and MUC-16 are present at the surface of BEC-derived EVs and have a protective role including neutralization of human influenza A virus infection by mucin-contained alpha 2, 6-sialic acids in Madin-Darby canine kidney (MDCK) cells [36]. A recent study showed that $80 \%$ of EVs in BALF from allergen-untreated mice were secreted from airway-lining epithelium by using cell-type-specific membrane tagging and single vesicle flow [37]. After induction of allergic airway inflammation by using ovalbumin (OVA), the number of immune cell-derived EVs including miR-223 and miR-142a in BALF from allergen-treated mice increased by more than twofold [37].

Table 1. The characteristics of extracellular vesicles in the respiratory system.

\begin{tabular}{|c|c|c|}
\hline Source & Function & Reference \\
\hline Bronchial epithelial cells & Regulate the normal airway biology including homeostasis and innate defense & [36] \\
\hline Macrophages & Maintain homeostasis and immune cell production & [38] \\
\hline Endothelial cells & Activate neighboring pericytes through proinflammatory microRNAs & [39] \\
\hline B cells & Activate immune system through antigen presentation & {$[40]$} \\
\hline Dendritic cells & Modulate immune reactions through activating $\mathrm{T}$ and $\mathrm{B}$ cells & {$[41,42]$} \\
\hline Mesenchymal stromal cells & Modulate the polarization of macrophages & [43] \\
\hline
\end{tabular}

Macrophages are also major sources of pulmonary EVs [30]. Macrophages secrete EVs, which induce macrophage differentiation through miRNA-223 transfer [38]. Alveolar macrophages infected with mycobacteria secrete EVs which contain pathogen-derived proinflammatory molecules and secrete heat-shock proteins (HSP)70, which activates the nuclear factor- $\mathrm{kB}$ (NF- $\mathrm{kB}$ ) pathway by stimulating toll-like receptors (TLRs) [44], leading to the secretion of proinflammatory cytokines [45,46]. Moreover, alveolar macrophages secrete EVs that contain suppressors of cytokine signaling (SOCS)-1 
and SOCS-3, resulting in inhibition of Janus kinase and signal transducers and activators of transcription signaling [47]. Macrophages secrete the procoagulant EVs in response to CSE [48]. CSE-induced macrophage-derived EVs upregulate the synthesis of proinflammatory mediators including IL-8, intercellular adhesion molecule-1 (ICAM-1), and monocyte chemotactic protein-1 (MCP-1) by lung epithelial cells [49]. CSE-induced macrophage-derived EVs have gelatinolytic and collagenolytic activities that are associated with a single transmembrane protease of the matrix metalloproteinase (MMP) superfamily [50].

Endothelial cells also secrete various types of EVs, including endothelial microparticles, which contain platelet endothelial cell adhesion molecule-1, vascular endothelial cadherin, and E-selectin, and have roles in coagulation, inflammation, endothelial function, and angiogenesis [33]. Activated human lung fibroblasts secrete EVs containing several prostaglandins (PGs), including high levels of the antifibrotic PGE2, and have roles in preventing myofibroblast differentiation and maintaining homeostasis [51].

Besides the cells mentioned above, it has been reported that B cells secrete EVs and have roles as immune-system activators [40]. Also, dendritic cells (DCs) secrete EVs and have roles in modulating immune reactions by activating $\mathrm{T}$ and $\mathrm{B}$ cells $[41,42]$. These findings suggest that EVs could regulate airway inflammation and allergic reactions through intercellular communications.

Mesenchymal stromal cells (MSCs) are recruited to inflammation sites [52], stimulate endogenous repair of injured tissues, and modulate immune response [53]. MSCs secrete EVs which are enriched in mRNAs [54]. For example, these EVs express mRNA for transcription factors including MDFIC, POU3F1, and NRIP1, and genes involved in angiogenesis including HGF, HES1, and TCF4 and genes involved in adipogenesis including CEBPA and KLF7 [55].

\subsection{Allergen-Induced Airway Inflammation}

Allergic inflammation is initiated with DC activation by allergens [56]. Activated DCs mature and present peptides derived from the processed allergen by major histocompatibility complex (MHC) class-II molecules to naïve T cells. DCs secrete the chemokines CC-chemokine ligand 17 (CCL17) and CCL22, which act on CC-chemokine receptor 4 to attract $T$ helper $2\left(\mathrm{~T}_{\mathrm{H}} 2\right)$ cells [57]. $\mathrm{T}_{\mathrm{H}} 2$ cells produce IL-4 and IL-13, which stimulate plasma B cells to secrete allergen-specific immunoglobulin $\mathrm{E}$ (IgE). Secreted $\operatorname{IgE}$ binds to the high-affinity receptor for $\operatorname{IgE}$ on tissue-resident mast cells in a process known as "sensitization". Thereafter, mast cells release three classes of biologically active product when they are re-exposed to the allergen: cytoplasmic granules (e.g., histamine) in a process known as "degranulation", lipid-derived mediators (e.g., PGs, leukotrienes), and cytokines, chemokines, and growth factors. Finally, these events cause vasodilation, increased vascular permeability, bronchoconstriction, and mucus secretion from airways [56]. Lipid-derived mediators drive airway inflammation, promote immune cell infiltration, and induce mucus hyperplasia. Indeed, leukotrienes promote mucus secretion, smooth-muscle contraction, and airway inflammation [58]. Ceramides and PGs also have a role in inflammation in the airways of BA patients [59-62]. $\mathrm{T}_{\mathrm{H}} 2$ cells produce IL-5, which has a crucial role in the differentiation, activation, and survival of eosinophils [63]. Eosinophils are associated with frequent exacerbations and fixed airflow limitation [64]. BA is orchestrated by IL-4-induced IgE-production and IL-5-induced expansion of eosinophils, which release proinflammatory and bronchoconstricting granular content [65]. When allergen exposure is repeated, innate immune cells including eosinophils, basophils, neutrophils, and monocytes, and adaptive immune cells including $\mathrm{T}$ and $\mathrm{B}$ cells take up residence in the inflammatory site. Then, complex interactions between innate immune cells and adaptive immune cells and lung structural cell are initiated, resulting in bronchoconstriction and severe narrowing of airway lumen. In some cases, $\mathrm{T}_{\mathrm{H}} 17$ also contributes to the recruitment of neutrophils to the inflammation site.

A recent study clarified the important role of regulatory $\mathrm{T}$ cells $\left(\mathrm{T}_{\mathrm{reg}}\right)$ in BA development. Indeed, induced $\mathrm{T}_{\text {reg }}$ cells suppress production of group- 2 innate lymphoid cell-driven IL- 5 and IL-13 [66]. Furthermore, recent studies have shown that IL-9, which is secreted by $\mathrm{T}_{\mathrm{H}} 9$ cells, is critically 
involved in the immune-pathogenesis of inflammatory diseases including BA and in guarding immune tolerance [67].

\subsection{Functions of EVs in BA Pathogenesis}

\subsubsection{EVs From Hematopoietic Cells}

EVs have a role in development, recruitment, activation, and suppression of the immune system $[9,17,40,68-74]$. Indeed, peripheral DCs secrete EVs, which are endocytosed and re-presented on the cell surface or transfer MHC/peptide complexes to recipient DCs after antigen uptake and processing [17,75-78]. These DC-derived EVs can activate T cells with assistance from DCs and B cells $[79,80]$. On the other hand, B cells also secrete EVs which express MHC, bind Bet v1-derived peptides, and, subsequently, induce dose-dependent $T$ cell proliferation [81]. The surface of B-cell-derived EVs contains clusters of differentiation (CD)40, CD80, and CD86, which have costimulatory capacity as well as integrins $(\alpha 1$ and $\alpha 2)$ and enable $B$ cells to exert important effects over $\mathrm{T}$ cell response $[72,82,83]$. Follicular DCs that lack the expression of MHC class II molecules received peptide-bound MHC class II molecules from EVs secreted by B cells $[84,85]$. Adhesion of EVs to the surface of follicular DCs is through the oligomerization and binding of tetraspanins between the EVs and follicular DCs [86]. In particular, ICAM-1, also known as CD54, facilitates this adhesion of EVs $[16,87,88]$. CD8 ${ }^{+}$DCs capture MHC-peptide complexes from EVs by the ligand for CD54, lymphocyte function-associated antigen-1 (LFA-1) [77]. Moreover, CD54/LFA-1 interactions on DCs are associated with internalization of EVs in immune cells [89]. Another study revealed that LFA-1 has a role in recruitment of EVs to T cells and their subsequent activation [90]. These findings suggest that EVs can modulate immune memory through expanding the repertoire of antigens [25].

EV production of monocyte-derived macrophages is modulated by transforming growth factor (TGF)- $\beta$, IL-1 $\beta$, and interferon (IFN)- $\gamma$ from airway smooth muscle. These cytokines affect the rate of exosome generation and delivery by peripheral blood monocytes or alveolar macrophages [30,38,91]. DCs and macrophages in humans secrete EVs which contain enzymes for leukotriene biosynthesis and which induce granulocyte migration [91]. This observation suggests that EVs have a proinflammatory role. Macrophages and DCs also secrete EVs which contain proinflammatory lipid mediators such as leukotrienes and promote migration of granulocyte [91]. Platelets also secrete EVs which transfer the leukotriene precursor arachidonic acid and induce leukotriene production in recipient platelets and endothelial cells [92]. Platelet-derived EVs promote adhesion of neutrophils to endothelial cells through CD62P and CXC chemokines [93]. Activated platelets adhere to intravascular neutrophils through P-selectin/P-selectin glycoprotein ligand-1 (PSGL-1)-mediated binding and allow platelets glycoprotein $\mathrm{Ib} \alpha(\mathrm{GPIb} \alpha)$-induced generation of neutrophil-derived EVs, which in turn synthesize thromboxane A2 [94]. Finally, platelet-derived thromboxane A2 elicits a full neutrophil response by inducing the endothelial expression of ICAM-1 and promotes neutrophil extravasation.

Eosinophils purified from peripheral blood can secrete EVs by IFN- $\gamma$ stimulation [95]. These EVs contain eosinophil-derived enzymes including eosinophil peroxidase (EPO), major basic protein (MBP), and eosinophil cationic protein (ECP) and have a role in BA.EVs from eosinophils of patients with $\mathrm{BA}$ act in an autocrine manner and can be distinguished from EVs from eosinophils of healthy subjects. Moreover, eosinophil-derived EVs increase reactive oxygen species (ROS) and nitric oxide (NO) production augmented chemotaxis of eosinophil and adhesion by upregulating ICAM-1 and integrin- $\alpha 2$ [96]. EVs from eosinophils of patients with BA can modify the behavior of small airway epithelial cells, increase their apoptosis, reduce their wound healing capacity, and enhance the expression of CCL26, TNF, and POSTN in epithelial cells and CCR3 and VEGFA in primary bronchial smooth muscle cells [97]. Neutrophil can also secrete EVs by lipopolysaccharides (LPS) stimulation [98]. These EVs are internalized by airway smooth muscle cells and their proliferative properties are altered. Furthermore, EVs containing leukotriene B4 act in an autocrine manner to sensitize neutrophils towards 
the primary chemoattractant, and in a paracrine manner to mediate the recruitment of neighboring neutrophils in trans [99].

\subsubsection{EVs from Lung Structural Cells}

EVs from pulmonary epithelial cells metabolize myeloid cell-derived leukotriene $\mathrm{C} 4$ to leukotriene D4 [100]. Furthermore, ceramides and sphingolipids are contained in EVs and have a role in inflammation $[101,102]$. In murine model of macrophage-mediated hepatic inflammation, ceramides of EVs act as chemoattractants of macrophages [103]. Tumor necrosis factor (TNF)- $\alpha$ and IFN- $\gamma$ induce the oligodendroglioma cell lines release of ceramide-enriched EVs as a mediator of cell death signaling [104]. IL-13 also induces EV secretion from epithelial cells, increasing chemotaxis and proliferation of macrophages [30]. Mechanical stress (e.g., bronchoconstriction) leads BECs to produce EVs, which have a role in promotion of subepithelial fibrosis and angiogenesis [105]. BEC-derived EVs also drive proliferation of monocytes and enhance chemotaxis [30]. EVs in BALF from BA patients express more clusters of differentiation-36, which has a role in bacterial infection-induced BA exacerbations through bacterial recognition compared with EVs in BALF from healthy controls [106]. $\mathrm{T}_{\mathrm{H}} 2$ cytokines can stimulate BEC production of EVs and induce monocyte proliferation. Moreover, monocytes which are treated with BEC-derived EVs enhance their migration in the presence of MCP-1 [25]. In addition to host cell-derived EVs, microbial EVs have a role in immune activation and hypersensitivity [107-109].

\subsubsection{Role of miRNA in EVs}

EVs can package miRNAs which have important roles in BA. miRNAs are small, noncoding RNAs, 20 to 23 nucleotides in length, packed within secreted EVs, and which regulate gene expression by destabilizing and degrading mRNAs [110-114]. A distinct set of extracellular miRNAs in induced sputum and BALF has also been identified as being associated with the respiratory tract $[31,115,116]$. In a rat study, serum EVs were identified with 16 different proinflammatory miRNAs in response to zinc oxide nanoparticles [117]. Additionally, miR-155 has a role in the development of infiltration of inflammatory cells into the lungs and in airway remodeling [118]. miR-155 expression is increased significantly in the lungs after allergen exposure, and miR-155-deficient mice have diminished eosinophilic inflammation in the lungs, suggesting that miR-155 is essential for $\mathrm{T}_{\mathrm{H}} 2$ cell-mediated inflammation [119]. miR-126 has a role in the effector function of $\mathrm{T}_{\mathrm{H}} 2$ cells, and antagonism of miR-126 suppresses allergic airway inflammation [120,121]. miR-27 and miR-24 are also important for $\mathrm{T}_{\mathrm{H}} 2$ response [122]. On the other hand, mir-21 has a role in metabolic regulation of pathogenic $\mathrm{T}_{\mathrm{H}} 17$ [123]. miR-221 has a role in mast-cell degranulation and cytokine production [124] and miR-221 blockade suppresses airway inflammation [125]. Furthermore, downregulation of miR-133a expression causes upregulation of RhoA expression, resulting in augmentation of airway contraction and hyperresponsiveness [126]. These findings suggest that EVs containing miRNA can modulate gene programming and promote inflammation in an antigen-independent manner.

\subsubsection{Novel Function of EVs}

Recent studies revealed that EVs have a role in transferring mitochondria, besides transferring bioactive materials [127-129]. Myeloid-derived regulatory cells transfer EVs containing mitochondria to peripheral $\mathrm{T}$ cells and regulate $\mathrm{T}$ cell responses in asthma [129]. MSC-derived EVs which contain mitochondria promote M2 polarization of macrophages and oxidative phosphorylation [128]. This novel finding suggests that EVs have a role in novel cell-cell communication involving EV transfer of mitochondria and the bioenergetics regulation of target cells.

\section{EVs as Potential Biomarkers of BA}

EVs in BALF from BA patients contain miRNAs and could be biomarkers of BA [31]. $\mathrm{EV}$ concentrations in BALF from BA patients increase and correlate with blood eosinophilia and serum 
IgE levels [88]. Several studies have revealed that the numbers of human leukocyte antigen D-related (HLA-DR) $^{+}$and ICAM- ${ }^{+}$EVs also increase in BALF from BA patients $[16,87,88,130]$. HLA-DR is a class-II antigen-presentation molecule on antigen-presenting cells [131]. ICAM-1 is an adhesion molecule and is expressed on the activated bronchial epithelial cells of BA patients [132]. Lipidomics has shown that levels of phosphatidylglycerol, ceramide-phosphates, and ceramides decrease in EVs in the BALF from BA patients [88]. Differential centrifugation with or without a gradient is a well-established purification method for EVs [133]. Commercial EV purification kits are also available [134]. Tetraspanins including CD63, CD9, CD81, CD82, HSP70, HSP90, tumor susceptibility gene 101 (TSG101), ALG-2 interacting protein X (ALIX), actin, and glyceraldehyde-3-phosphate dehydrogenase (GAPDH) are used as cell surface markers to identify EVs [135-137]. Generally, tetraspanins, integrins, cell-adhesion molecules, proteoglycans, and lectins are associated with cell-cell interactions and triggering signaling transduction [138]. Endosomal sorting complexes required for transport (ESCRT) including TSG101, CD81, and ALIX are used as endosomal markers $[110,139]$. Surprisingly, it has been reported that EVs in exhaled breath condensates (EBCs) from BA patients can be noninvasive biomarkers of BA $[140,141]$. However, miRNAs in serum are more suitable biomarkers than those in BALF or EBCs in clinical settings [142].

\section{EVs as Potential Therapeutic Targets for BA}

EVs in the BALF of patients with BA increased IL-4 and leukotriene C4 in BECs [87]. Administration of BALF-derived EVs from experimental mice with BA inhibits IgE responses, $\mathrm{T}_{\mathrm{H}} 2$ cytokine production, and airway inflammation [29]. EV secretion has been reported to be prevented by GW4869, which inhibits neutral sphingomyelinase-2 (a key regulatory enzyme that generates ceramide from sphingomyelin) [143-152]. In the murine house dust mite (HDM)-induced asthma model, EVs in BALF from HDM-exposed mice are 8.9-fold higher than those from sham-control mice [153]. HDM induced significant changes in the expression of 139 miRNAs in EVs and upregulated 31 genes including IL-13 and IL-5Ra that are putative targets of the miR-346 and miR-574-5p, respectively. GW4869 administration reduces EV secretion and ameliorates BA in mice [30,153]. Systemic administration of EVs secreted by human MSCs ameliorates eosinophilic and neutrophilic airway allergic inflammation in experimental mice [154]. EVs secreted by MSCs promote the proliferation and immune-suppression capacity of $T_{\text {reg }}$ cells by upregulating expression of IL- 10 and transforming growth factor- $\beta 1$ from peripheral blood mononuclear cells [155]. Two safety studies of MSCs and their trophic factors in BA patients are in progress (NCT02192736 and NCT03137199).

EVs are useful in drug delivery, since EVs can reduce toxicity, carry both lipophilic and hydrophilic drugs to target cells, and preserve drugs' therapeutic activity $[156,157]$. In order to preserve drugs' therapeutic activity, two distinct methods of loading molecular cargo into exosome have been developed. Briefly, passive methods incubate hydrophobic agents and EVs. On the other hand, active methods use extrusion, sonication, or electroporation techniques. Mast cell- and DC-derived EVs display a specific lipid composition and are stable in circulation [158] and are protected from complement-mediated lysis by expression of CD55 and CD59 [159]. Moreover, EVs can deliver therapeutic biomolecules ranging from nucleic acids to small molecules. For example, EVs loaded with curcumin lead to an increase in the stability of curcumin in vitro and bioavailability in vivo [160]. Genetically engineered EVs carrying suicide gene mRNA and protein-cytosine deaminase fused to uracil phosphoribosyltransferase reduce schwannoma tumor growth [161]. Targeted drug delivery vesicles with low immunogenicity and toxicity were developed by electroporation technology [162]. This approach has been used to load small-molecule drugs and small interfering RNA (siRNA) [163]. However, electroporation of EVs with siRNA requires careful attention, since electroporation causes extensive siRNA aggregate formation, resulting in overestimation of the amount of siRNA actually loaded into EVs [164]. Unique trehalose pulse media is reported to minimize exosome aggregation following electroporation [165], suggesting that it may be possible to reduce aggregation of EVs and cargo RNA by optimizing electroporation conditions. 
Another strategy for loading therapeutically active cargo molecules into EVs uses hydrophobic agents, which are incubated with EVs or donor cells [166]. Interestingly, most of the cells incubated with chemotherapeutic agents or nucleic acids can package these molecules into EVs. Indeed, DCs have been used in several experimental settings as EV donor cells due to their low immunogenicity profile. EVs released from indoleamine 2,3-dioxygenase (IDO)-expressing DCs have anti-inflammatory effects, and are able to reverse arthritis in a murine model of collagen-induced disease [167]. MSCs are promising sources of EVs for drug delivery in the treatment of several disorders, since they can repair tissues and have immunomodulatory properties. Indeed, intravenous delivery of MSC-derived EVs improves functional recovery and promotes neuroplasticity in young adult male rats [168]. Viral packing strategy is one of the approaches for loading nucleic acids into EVs. Nonenveloped viruses such as adeno-associated virus [169] and hepatitis A virus [170] can be incorporated into EVs during propagation.

The technologies for EV isolation are critical for future applications of EVs as drug delivery vehicles. The differential centrifugations followed by ultracentrifugation are commonly used to remove cells and large cell debris and precipitate EVs $[133,171]$. Another EV isolation technique is based on precipitation by polymers [172-174] or size exclusion chromatography (SEC) $[175,176]$. SEC has proven to be beneficial in the elimination of contaminants such as proteins and lipoproteins [177]. Lastly, ultrafiltration involving the use of membranes with specific pore size is a suitable approach for rapid EV purification from large volume samples and allows a high degree of purification when it is combined with SEC [178-180].

\section{Conclusions}

In the respiratory system, EVs are secreted from all types of hematopoietic cells and lung structural cells and have a role in intercellular communication, modulating antigen presentation and immune activation, suppression, and surveillance. BA is a chronic inflammatory disease of the airways with a complex pathophysiology that involves hematopoietic cells, including DCs, T and B cells, monocytes, and eosinophils, and lung structural cells. Several studies revealed EVs in BALF and EBC from BA patients could be biomarkers of BA. EVs are potential therapeutic targets for BA and two safety studies of MSCs and their trophic factors in BA patients are in progress. Although EVs are biologically well studied and are promising biomarkers and therapeutic targets for asthma, several clinical trials are required for clinical application.

Author Contributions: Conceptualization, T.N. and K.U.; resources, M.K., R.D., D.H., and T.K.; writing-preparation of the original draft, T.N. and K.K.; writing-review and editing, T.N., M.K., R.D., D.H., T.K., K.U., K.K., and Y.N.; supervision, Y.N.; project administration, Y.N.

Funding: This research received no external funding.

Acknowledgments: We thank the members of the Division of Respiratory Medicine within Kobe University Graduate School of Medicine for helpful discussions.

Conflicts of Interest: The authors declare no conflict of interest.

\section{Abbreviations}

$\begin{array}{ll}\text { ALIX } & \text { ALG-2 interacting protein X } \\ \text { BA } & \text { Bronchial asthma } \\ \text { BALF } & \text { Bronchoalveolar lavage fluid } \\ \text { BEC } & \text { Bronchial epithelial cell } \\ \text { CCL } & \text { CC-chemokine ligand } \\ \text { CCR } & \text { CC-chemokine receptor } \\ \text { CD } & \text { Cluster of differentiation } \\ \text { CSE } & \text { Cigarette smoke extract } \\ \text { DC } & \text { Dendritic cell } \\ \text { EBC } & \text { Exhaled breath condensate }\end{array}$




$\begin{array}{ll}\text { ECP } & \text { Eosinophil cationic protein } \\ \text { EPO } & \text { Eosinophil peroxidase } \\ \text { ESCRT } & \text { Endosomal sorting complexes required for transport } \\ \text { EV } & \text { Extracellular vesicle } \\ \text { GAPDH } & \text { Glyceraldehyde-3-phosphate dehydrogenase } \\ \text { GPIb } \alpha & \text { Glycoprotein Ib } \alpha \\ \text { HDM } & \text { House-dust mite } \\ \text { HLA-DR } & \text { Human leukocyte antigen D-related } \\ \text { HSP } & \text { Heat-shock protein } \\ \text { ICAM-1 } & \text { Intercellular adhesion molecule-1 } \\ \text { IDO } & \text { Indoleamine 2,3-dioxygenase } \\ \text { Ig } & \text { Immunoglobulin } \\ \text { IL } & \text { Interleukin } \\ \text { LPS } & \text { Lipopolysaccharide } \\ \text { MBP } & \text { Major basic protein } \\ \text { MCP-1 } & \text { Monocyte chemotactic protein-1 } \\ \text { MDCK } & \text { Madin-Darby canine kidney cell } \\ \text { MHC } & \text { Major histocompatibility complex } \\ \text { MMP } & \text { Matrix metalloproteinase } \\ \text { mRNA } & \text { Messenger RNA } \\ \text { MSC } & \text { Mesenchymal stromal cell } \\ \text { MUC } & \text { Mucin } \\ \text { NO } & \text { Nitric oxide } \\ \text { OVA } & \text { Ovalbumin } \\ \text { PG } & \text { Prostaglandin } \\ \text { PSGL-1 } & \text { P-selectin/P-selectin glycoprotein ligand-1 } \\ \text { ROS } & \text { Reactive oxygen species } \\ \text { SEC } & \text { Size exclusion chromatography } \\ \text { siRNA } & \text { Small interfering RNA } \\ \text { SOCS } & \text { Suppressor of cytokine signaling } \\ \mathrm{T}_{\mathrm{H}} & \text { T helper } \\ \text { TLR } & \text { Toll-like receptor } \\ \mathrm{T}_{\text {reg }} & \text { T regulatory } \\ \text { TSG } & \text { Tumor susceptibility } \\ \text { VEGF } & \text { Vascular endothelial growth factor } \\ & \end{array}$

\section{References}

1. Wolf, P. The nature and significance of platelet products in human plasma. Br. J. Haematol. 1967, 13, $269-288$. [CrossRef] [PubMed]

2. Trams, E.G.; Lauter, C.J.; Salem, N.; Heine, U. Exfoliation of membrane ecto-enzymes in the form of micro-vesicles. Biochim. Biophys. Acta 1981, 645, 63-70. [CrossRef]

3. Becker, A.; Thakur, B.K.; Weiss, J.M.; Kim, H.S.; Peinado, H.; Lyden, D. Extracellular Vesicles in Cancer: Cell-to-Cell Mediators of Metastasis. Cancer Cell 2016, 30, 836-848. [CrossRef]

4. György, B.; Szabó, T.G.; Pásztói, M.; Pál, Z.; Misják, P.; Aradi, B.; László, V.; Pállinger, E.; Pap, E.; Kittel, A.; et al. Membrane vesicles, current state-of-the-art: Emerging role of extracellular vesicles. Cell Mol. Life Sci. 2011, 68, 2667-2688. [CrossRef] [PubMed]

5. Hurley, J.H.; Boura, E.; Carlson, L.A.; Różycki, B. Membrane budding. Cell 2010, 143, 875-887. [CrossRef] [PubMed]

6. Saez, F.; Frenette, G.; Sullivan, R. Epididymosomes and prostasomes: Their roles in posttesticular maturation of the sperm cells. J. Androl. 2003, 24, 149-154. [CrossRef]

7. Forterre, A.; Jalabert, A.; Chikh, K.; Pesenti, S.; Euthine, V.; Granjon, A.; Errazuriz, E.; Lefai, E.; Vidal, H.; Rome, S. Myotube-derived exosomal miRNAs downregulate Sirtuin1 in myoblasts during muscle cell differentiation. Cell Cycle 2014, 13, 78-89. [CrossRef] [PubMed] 
8. Camussi, G.; Deregibus, M.C.; Bruno, S.; Cantaluppi, V.; Biancone, L. Exosomes/microvesicles as a mechanism of cell-to-cell communication. Kidney Int. 2010, 78, 838-848. [CrossRef]

9. Robbins, P.D.; Morelli, A.E. Regulation of immune responses by extracellular vesicles. Nat. Rev. Immunol. 2014, 14, 195-208. [CrossRef] [PubMed]

10. Takeuchi, T.; Suzuki, M.; Fujikake, N.; Popiel, H.A.; Kikuchi, H.; Futaki, S.; Wada, K.; Nagai, Y. Intercellular chaperone transmission via exosomes contributes to maintenance of protein homeostasis at the organismal level. Proc. Natl. Acad. Sci. USA 2015, 112, E2497-E2506. [CrossRef]

11. Baixauli, F.; López-Otín, C.; Mittelbrunn, M. Exosomes and autophagy: Coordinated mechanisms for the maintenance of cellular fitness. Front. Immunol. 2014, 5, 403. [CrossRef] [PubMed]

12. Aswad, H.; Forterre, A.; Wiklander, O.P.; Vial, G.; Danty-Berger, E.; Jalabert, A.; Lamazière, A.; Meugnier, E.; Pesenti, S.; Ott, C.; et al. Exosomes participate in the alteration of muscle homeostasis during lipid-induced insulin resistance in mice. Diabetologia 2014, 57, 2155-2164. [CrossRef] [PubMed]

13. Caby, M.P.; Lankar, D.; Vincendeau-Scherrer, C.; Raposo, G.; Bonnerot, C. Exosomal-like vesicles are present in human blood plasma. Int. Immunol. 2005, 17, 879-887. [CrossRef]

14. Pisitkun, T.; Shen, R.F.; Knepper, M.A. Identification and proteomic profiling of exosomes in human urine. Proc. Natl. Acad. Sci. USA 2004, 101, 13368-13373. [CrossRef]

15. Admyre, C.; Johansson, S.M.; Qazi, K.R.; Filén, J.J.; Lahesmaa, R.; Norman, M.; Neve, E.P.; Scheynius, A.; Gabrielsson, S. Exosomes with immune modulatory features are present in human breast milk. J. Immunol. 2007, 179, 1969-1978. [CrossRef]

16. Admyre, C.; Grunewald, J.; Thyberg, J.; Gripenbäck, S.; Tornling, G.; Eklund, A.; Scheynius, A.; Gabrielsson, S. Exosomes with major histocompatibility complex class II and co-stimulatory molecules are present in human BAL fluid. Eur. Respir. J. 2003, 22, 578-583. [CrossRef] [PubMed]

17. Théry, C.; Ostrowski, M.; Segura, E. Membrane vesicles as conveyors of immune responses. Nat. Rev. Immunol. 2009, 9, 581-593. [CrossRef]

18. Cocucci, E.; Racchetti, G.; Meldolesi, J. Shedding microvesicles: Artefacts no more. Trends Cell Biol. 2009, 19, 43-51. [CrossRef] [PubMed]

19. Hristov, M.; Erl, W.; Linder, S.; Weber, P.C. Apoptotic bodies from endothelial cells enhance the number and initiate the differentiation of human endothelial progenitor cells in vitro. Blood 2004, 104, 2761-2766. [CrossRef]

20. Raposo, G.; Stoorvogel, W. Extracellular vesicles: Exosomes, microvesicles, and friends. J. Cell Biol. 2013, 200, 373-383. [CrossRef]

21. Ciardiello, C.; Cavallini, L.; Spinelli, C.; Yang, J.; Reis-Sobreiro, M.; de Candia, P.; Minciacchi, V.R.; Di Vizio, D. Focus on Extracellular Vesicles: New Frontiers of Cell-to-Cell Communication in Cancer. Int. J. Mol. Sci. 2016, 17, 175. [CrossRef]

22. Dörsam, B.; Reiners, K.S.; von Strandmann, E.P. Cancer-derived extracellular vesicles: Friend and foe of tumour immunosurveillance. Philos. Trans. R. Soc. B Biol. Sci. 2018, 373. [CrossRef]

23. Schorey, J.S.; Cheng, Y.; Singh, P.P.; Smith, V.L. Exosomes and other extracellular vesicles in host-pathogen interactions. EMBO Rep. 2015, 16, 24-43. [CrossRef]

24. Zhang, Y.; Hu, Y.W.; Zheng, L.; Wang, Q. Characteristics and Roles of Exosomes in Cardiovascular Disease. DNA Cell Biol. 2017, 36, 202-211. [CrossRef]

25. Hough, K.P.; Chanda, D.; Duncan, S.R.; Thannickal, V.J.; Deshane, J.S. Exosomes in immunoregulation of chronic lung diseases. Allergy 2017, 72, 534-544. [CrossRef]

26. Sastre, B.; Cañas, J.A.; Rodrigo-Muñoz, J.M.; Del Pozo, V. Novel Modulators of Asthma and Allergy: Exosomes and MicroRNAs. Front. Immunol. 2017, 8, 826. [CrossRef]

27. Mortaz, E.; Alipoor, S.D.; Varahram, M.; Jamaati, H.; Garssen, J.; Mumby, S.E.; Adcock, I.M. Exosomes in Severe Asthma: Update in Their Roles and Potential in Therapy. Biomed Res. Int. 2018, 2018, 2862187. [CrossRef]

28. Wahlund, C.J.E.; Eklund, A.; Grunewald, J.; Gabrielsson, S. Pulmonary Extracellular Vesicles as Mediators of Local and Systemic Inflammation. Front. Cell Dev. Biol. 2017, 5, 39. [CrossRef]

29. Prado, N.; Marazuela, E.G.; Segura, E.; Fernández-García, H.; Villalba, M.; Théry, C.; Rodríguez, R.; Batanero, E. Exosomes from bronchoalveolar fluid of tolerized mice prevent allergic reaction. J. Immunol. 2008, 181, 1519-1525. [CrossRef] 
30. Kulshreshtha, A.; Ahmad, T.; Agrawal, A.; Ghosh, B. Proinflammatory role of epithelial cell-derived exosomes in allergic airway inflammation. J. Allergy Clin. Immunol. 2013, 131, 1194-1203.e14. [CrossRef]

31. Levänen, B.; Bhakta, N.R.; Torregrosa Paredes, P.; Barbeau, R.; Hiltbrunner, S.; Pollack, J.L.; Sköld, C.M.; Svartengren, M.; Grunewald, J.; Gabrielsson, S.; et al. Altered microRNA profiles in bronchoalveolar lavage fluid exosomes in asthmatic patients. J. Allergy Clin. Immunol. 2013, 131, 894-903. [CrossRef]

32. Denzer, K.; Kleijmeer, M.J.; Heijnen, H.F.; Stoorvogel, W.; Geuze, H.J. Exosome: From internal vesicle of the multivesicular body to intercellular signaling device. J. Cell Sci. 2000, 113 Pt 19, 3365-3374.

33. Kadota, T.; Fujita, Y.; Yoshioka, Y.; Araya, J.; Kuwano, K.; Ochiya, T. Extracellular Vesicles in Chronic Obstructive Pulmonary Disease. Int. J. Mol. Sci. 2016, 17. [CrossRef]

34. Moon, H.G.; Kim, S.H.; Gao, J.; Quan, T.; Qin, Z.; Osorio, J.C.; Rosas, I.O.; Wu, M.; Tesfaigzi, Y.; Jin, Y. CCN1 secretion and cleavage regulate the lung epithelial cell functions after cigarette smoke. Am. J. Physiol. Lung Cell Mol. Physiol. 2014, 307, L326-L337. [CrossRef]

35. Kesimer, M.; Gupta, R. Physical characterization and profiling of airway epithelial derived exosomes using light scattering. Methods 2015, 87, 59-63. [CrossRef]

36. Kesimer, M.; Scull, M.; Brighton, B.; DeMaria, G.; Burns, K.; O’Neal, W.; Pickles, R.J.; Sheehan, J.K. Characterization of exosome-like vesicles released from human tracheobronchial ciliated epithelium: A possible role in innate defense. FASEB J. 2009, 23, 1858-1868. [CrossRef]

37. Pua, H.H.; Happ, H.C.; Gray, C.J.; Mar, D.J.; Chiou, N.T.; Hesse, L.E.; Ansel, K.M. Increased Hematopoietic Extracellular RNAs and Vesicles in the Lung during Allergic Airway Responses. Cell Rep. 2019, 26, 933-944.e4. [CrossRef]

38. Ismail, N.; Wang, Y.; Dakhlallah, D.; Moldovan, L.; Agarwal, K.; Batte, K.; Shah, P.; Wisler, J.; Eubank, T.D.; Tridandapani, S.; et al. Macrophage microvesicles induce macrophage differentiation and miR-223 transfer. Blood 2013, 121, 984-995. [CrossRef]

39. Yamamoto, S.; Niida, S.; Azuma, E.; Yanagibashi, T.; Muramatsu, M.; Huang, T.T.; Sagara, H.; Higaki, S.; Ikutani, M.; Nagai, Y.; et al. Inflammation-induced endothelial cell-derived extracellular vesicles modulate the cellular status of pericytes. Sci. Rep. 2015, 5, 8505. [CrossRef]

40. Raposo, G.; Nijman, H.W.; Stoorvogel, W.; Liejendekker, R.; Harding, C.V.; Melief, C.J.; Geuze, H.J. B lymphocytes secrete antigen-presenting vesicles. J. Exp. Med. 1996, 183, 1161-1172. [CrossRef]

41. Zitvogel, L.; Regnault, A.; Lozier, A.; Wolfers, J.; Flament, C.; Tenza, D.; Ricciardi-Castagnoli, P.; Raposo, G.; Amigorena, S. Eradication of established murine tumors using a novel cell-free vaccine: Dendritic cell-derived exosomes. Nat. Med. 1998, 4, 594-600. [CrossRef]

42. Skokos, D.; Le Panse, S.; Villa, I.; Rousselle, J.C.; Peronet, R.; David, B.; Namane, A.; Mécheri, S. Mast cell-dependent B and T lymphocyte activation is mediated by the secretion of immunologically active exosomes. J. Immunol. 2001, 166, 868-876. [CrossRef]

43. Ti, D.; Hao, H.; Tong, C.; Liu, J.; Dong, L.; Zheng, J.; Zhao, Y.; Liu, H.; Fu, X.; Han, W. LPS-preconditioned mesenchymal stromal cells modify macrophage polarization for resolution of chronic inflammation via exosome-shuttled let-7b. J. Transl. Med. 2015, 13, 308. [CrossRef]

44. Fujita, Y.; Kosaka, N.; Araya, J.; Kuwano, K.; Ochiya, T. Extracellular vesicles in lung microenvironment and pathogenesis. Trends Mol Med 2015, 21, 533-542. [CrossRef] [PubMed]

45. Biancone, L.; Bruno, S.; Deregibus, M.C.; Tetta, C.; Camussi, G. Therapeutic potential of mesenchymal stem cell-derived microvesicles. Nephrol. Dial Transplant. 2012, 27, 3037-3042. [CrossRef]

46. Bruno, S.; Deregibus, M.C.; Camussi, G. The secretome of mesenchymal stromal cells: Role of extracellular vesicles in immunomodulation. Immunol. Lett. 2015, 168, 154-158. [CrossRef]

47. Bourdonnay, E.; Zasłona, Z.; Penke, L.R.; Speth, J.M.; Schneider, D.J.; Przybranowski, S.; Swanson, J.A.; Mancuso, P.; Freeman, C.M.; Curtis, J.L.; et al. Transcellular delivery of vesicular SOCS proteins from macrophages to epithelial cells blunts inflammatory signaling. J. Exp. Med. 2015, 212, 729-742. [CrossRef]

48. Li, M.; Yu, D.; Williams, K.J.; Liu, M.L. Tobacco smoke induces the generation of procoagulant microvesicles from human monocytes/macrophages. Arterioscler. Thromb. Vasc. Biol. 2010, 30, 1818-1824. [CrossRef]

49. Cordazzo, C.; Petrini, S.; Neri, T.; Lombardi, S.; Carmazzi, Y.; Pedrinelli, R.; Paggiaro, P.; Celi, A. Rapid shedding of proinflammatory microparticles by human mononuclear cells exposed to cigarette smoke is dependent on Ca2+ mobilization. Inflamm. Res. 2014, 63, 539-547. [CrossRef]

50. Li, C.J.; Liu, Y.; Chen, Y.; Yu, D.; Williams, K.J.; Liu, M.L. Novel proteolytic microvesicles released from human macrophages after exposure to tobacco smoke. Am. J. Pathol. 2013, 182, 1552-1562. [CrossRef] 
51. Lacy, S.H.; Woeller, C.F.; Thatcher, T.H.; Pollock, S.J.; Small, E.M.; Sime, P.J.; Phipps, R.P. Activated Human Lung Fibroblasts Produce Extracellular Vesicles with Antifibrotic Prostaglandins. Am. J. Respir. Cell Mol. Biol. 2019, 60, 269-278. [CrossRef] [PubMed]

52. Hofmann, N.A.; Ortner, A.; Jacamo, R.O.; Reinisch, A.; Schallmoser, K.; Rohban, R.; Etchart, N.; Fruehwirth, M.; Beham-Schmid, C.; Andreeff, M.; et al. Oxygen sensing mesenchymal progenitors promote neo-vasculogenesis in a humanized mouse model in vivo. PLoS ONE 2012, 7, e44468. [CrossRef] [PubMed]

53. Zhao, S.; Wehner, R.; Bornhäuser, M.; Wassmuth, R.; Bachmann, M.; Schmitz, M. Immunomodulatory properties of mesenchymal stromal cells and their therapeutic consequences for immune-mediated disorders. Stem Cells Dev. 2010, 19, 607-614. [CrossRef] [PubMed]

54. Tomasoni, S.; Longaretti, L.; Rota, C.; Morigi, M.; Conti, S.; Gotti, E.; Capelli, C.; Introna, M.; Remuzzi, G.; Benigni, A. Transfer of growth factor receptor mRNA via exosomes unravels the regenerative effect of mesenchymal stem cells. Stem Cells Dev. 2013, 22, 772-780. [CrossRef]

55. Eirin, A.; Riester, S.M.; Zhu, X.Y.; Tang, H.; Evans, J.M.; O’Brien, D.; van Wijnen, A.J.; Lerman, L.O. MicroRNA and mRNA cargo of extracellular vesicles from porcine adipose tissue-derived mesenchymal stem cells. Gene 2014, 551, 55-64. [CrossRef]

56. Galli, S.J.; Tsai, M.; Piliponsky, A.M. The development of allergic inflammation. Nature 2008, 454, 445-454. [CrossRef] [PubMed]

57. Barnes, P.J. Immunology of asthma and chronic obstructive pulmonary disease. Nat. Rev. Immunol. 2008, 8, 183-192. [CrossRef]

58. Schauberger, E.; Peinhaupt, M.; Cazares, T.; Lindsley, A.W. Lipid Mediators of Allergic Disease: Pathways, Treatments, and Emerging Therapeutic Targets. Curr. Allergy Asthma Rep. 2016, 16, 48. [CrossRef]

59. Luster, A.D.; Tager, A.M. T-cell trafficking in asthma: Lipid mediators grease the way. Nat. Rev. Immunol. 2004, 4, 711-724. [CrossRef]

60. Matsuoka, T.; Hirata, M.; Tanaka, H.; Takahashi, Y.; Murata, T.; Kabashima, K.; Sugimoto, Y.; Kobayashi, T.; Ushikubi, F.; Aze, Y.; et al. Prostaglandin D2 as a mediator of allergic asthma. Science 2000, 287, 2013-2017. [CrossRef]

61. Ono, J.G.; Worgall, T.S.; Worgall, S. Airway reactivity and sphingolipids-implications for childhood asthma. Mol. Cell Pediatr. 2015, 2, 13. [CrossRef]

62. Calder, P.C.; Grimble, R.F. Polyunsaturated fatty acids, inflammation and immunity. Eur. J. Clin. Nutr. 2002, 56 (Suppl. 3), S14-S19. [CrossRef]

63. Legrand, F.; Klion, A.D. Biologic therapies targeting eosinophils: Current status and future prospects. J. Allergy Clin. Immunol. Pract. 2015, 3, 167-174. [CrossRef]

64. Bel, E.H.; Ten Brinke, A. New Anti-Eosinophil Drugs for Asthma and COPD: Targeting the Trait! Chest 2017, 152, 1276-1282. [CrossRef]

65. Lambrecht, B.N.; Hammad, H. The immunology of asthma. Nat. Immunol. 2015, 16, 45-56. [CrossRef]

66. Aron, J.L.; Akbari, O. Regulatory T cells and type 2 innate lymphoid cell-dependent asthma. Allergy 2017, 72, 1148-1155. [CrossRef]

67. Chakraborty, S.; Kubatzky, K.F.; Mitra, D.K. An Update on Interleukin-9: From Its Cellular Source and Signal Transduction to Its Role in Immunopathogenesis. Int. J. Mol. Sci. 2019, 20. [CrossRef]

68. Simhadri, V.R.; Reiners, K.S.; Hansen, H.P.; Topolar, D.; Simhadri, V.L.; Nohroudi, K.; Kufer, T.A.; Engert, A.; Pogge von Strandmann, E. Dendritic cells release HLA-B-associated transcript-3 positive exosomes to regulate natural killer function. PLoS ONE 2008, 3, e3377. [CrossRef]

69. Viaud, S.; Terme, M.; Flament, C.; Taieb, J.; André, F.; Novault, S.; Escudier, B.; Robert, C.; Caillat-Zucman, S.; Tursz, T.; et al. Dendritic cell-derived exosomes promote natural killer cell activation and proliferation: A role for NKG2D ligands and IL-15Ralpha. PLoS ONE 2009, 4, e4942. [CrossRef]

70. Utsugi-Kobukai, S.; Fujimaki, H.; Hotta, C.; Nakazawa, M.; Minami, M. MHC class I-mediated exogenous antigen presentation by exosomes secreted from immature and mature bone marrow derived dendritic cells. Immunol. Lett. 2003, 89, 125-131. [CrossRef]

71. Luketic, L.; Delanghe, J.; Sobol, P.T.; Yang, P.; Frotten, E.; Mossman, K.L.; Gauldie, J.; Bramson, J.; Wan, Y. Antigen presentation by exosomes released from peptide-pulsed dendritic cells is not suppressed by the presence of active CTL. J. Immunol. 2007, 179, 5024-5032. [CrossRef]

72. Muntasell, A.; Berger, A.C.; Roche, P.A. T cell-induced secretion of MHC class II-peptide complexes on B cell exosomes. EMBO J. 2007, 26, 4263-4272. [CrossRef] [PubMed] 
73. Huber, V.; Fais, S.; Iero, M.; Lugini, L.; Canese, P.; Squarcina, P.; Zaccheddu, A.; Colone, M.; Arancia, G.; Gentile, M.; et al. Human colorectal cancer cells induce T-cell death through release of proapoptotic microvesicles: Role in immune escape. Gastroenterology 2005, 128, 1796-1804. [CrossRef] [PubMed]

74. Andreola, G.; Rivoltini, L.; Castelli, C.; Huber, V.; Perego, P.; Deho, P.; Squarcina, P.; Accornero, P.; Lozupone, F.; Lugini, L.; et al. Induction of lymphocyte apoptosis by tumor cell secretion of FasL-bearing microvesicles. J. Exp. Med. 2002, 195, 1303-1316. [CrossRef] [PubMed]

75. André, F.; Chaput, N.; Schartz, N.E.; Flament, C.; Aubert, N.; Bernard, J.; Lemonnier, F.; Raposo, G.; Escudier, B.; Hsu, D.H.; et al. Exosomes as potent cell-free peptide-based vaccine. I. Dendritic cell-derived exosomes transfer functional MHC class I/peptide complexes to dendritic cells. J. Immunol. 2004, 172, 2126-2136. [CrossRef] [PubMed]

76. Théry, C.; Regnault, A.; Garin, J.; Wolfers, J.; Zitvogel, L.; Ricciardi-Castagnoli, P.; Raposo, G.; Amigorena, S. Molecular characterization of dendritic cell-derived exosomes. Selective accumulation of the heat shock protein hsc73. J. Cell Biol. 1999, 147, 599-610. [CrossRef]

77. Segura, E.; Guérin, C.; Hogg, N.; Amigorena, S.; Théry, C. CD8+ dendritic cells use LFA-1 to capture MHC-peptide complexes from exosomes in vivo. J. Immunol. 2007, 179, 1489-1496. [CrossRef]

78. Campana, S.; De Pasquale, C.; Carrega, P.; Ferlazzo, G.; Bonaccorsi, I. Cross-dressing: An alternative mechanism for antigen presentation. Immunol. Lett. 2015, 168, 349-354. [CrossRef]

79. Théry, C.; Duban, L.; Segura, E.; Véron, P.; Lantz, O.; Amigorena, S. Indirect activation of naïve CD4+ T cells by dendritic cell-derived exosomes. Nat. Immunol. 2002, 3, 1156-1162. [CrossRef]

80. Näslund, T.I.; Gehrmann, U.; Qazi, K.R.; Karlsson, M.C.; Gabrielsson, S. Dendritic cell-derived exosomes need to activate both $\mathrm{T}$ and $\mathrm{B}$ cells to induce antitumor immunity. J. Immunol. 2013, 190, 2712-2719. [CrossRef] [PubMed]

81. Admyre, C.; Bohle, B.; Johansson, S.M.; Focke-Tejkl, M.; Valenta, R.; Scheynius, A.; Gabrielsson, S. $\mathrm{B}$ cell-derived exosomes can present allergen peptides and activate allergen-specific $\mathrm{T}$ cells to proliferate and produce TH2-like cytokines. J. Allergy Clin. Immunol. 2007, 120, 1418-1424. [CrossRef]

82. Buschow, S.I.; van Balkom, B.W.; Aalberts, M.; Heck, A.J.; Wauben, M.; Stoorvogel, W. MHC class II-associated proteins in B-cell exosomes and potential functional implications for exosome biogenesis. Immunol. Cell Biol. 2010, 88, 851-856. [CrossRef]

83. Clayton, A.; Turkes, A.; Dewitt, S.; Steadman, R.; Mason, M.D.; Hallett, M.B. Adhesion and signaling by B cell-derived exosomes: The role of integrins. FASEB J. 2004, 18, 977-979. [CrossRef]

84. Denzer, K.; van Eijk, M.; Kleijmeer, M.J.; Jakobson, E.; de Groot, C.; Geuze, H.J. Follicular dendritic cells carry MHC class II-expressing microvesicles at their surface. J. Immunol. 2000, 165, 1259-1265. [CrossRef] [PubMed]

85. Gray, D.; Kosco, M.; Stockinger, B. Novel pathways of antigen presentation for the maintenance of memory. Int. Immunol. 1991, 3, 141-148. [CrossRef]

86. Hough, K.P.; Deshane, J.S. Exosomes in Allergic Airway Diseases. Curr. Allergy Asthma Rep. 2019, $19,26$. [CrossRef] [PubMed]

87. Torregrosa Paredes, P.; Esser, J.; Admyre, C.; Nord, M.; Rahman, Q.K.; Lukic, A.; Rådmark, O.; Grönneberg, R.; Grunewald, J.; Eklund, A.; et al. Bronchoalveolar lavage fluid exosomes contribute to cytokine and leukotriene production in allergic asthma. Allergy 2012, 67, 911-919. [CrossRef]

88. Hough, K.P.; Wilson, L.S.; Trevor, J.L.; Strenkowski, J.G.; Maina, N.; Kim, Y.I.; Spell, M.L.; Wang, Y.; Chanda, D.; Dager, J.R.; et al. Unique Lipid Signatures of Extracellular Vesicles from the Airways of Asthmatics. Sci. Rep. 2018, 8, 10340. [CrossRef]

89. Hao, S.; Bai, O.; Li, F.; Yuan, J.; Laferte, S.; Xiang, J. Mature dendritic cells pulsed with exosomes stimulate efficient cytotoxic T-lymphocyte responses and antitumour immunity. Immunology 2007, 120, 90-102. [CrossRef] [PubMed]

90. Nolte-'t Hoen, E.N.; Buschow, S.I.; Anderton, S.M.; Stoorvogel, W.; Wauben, M.H. Activated T cells recruit exosomes secreted by dendritic cells via LFA-1. Blood 2009, 113, 1977-1981. [CrossRef]

91. Esser, J.; Gehrmann, U.; D'Alexandri, F.L.; Hidalgo-Estévez, A.M.; Wheelock, C.E.; Scheynius, A.; Gabrielsson, S.; Rådmark, O. Exosomes from human macrophages and dendritic cells contain enzymes for leukotriene biosynthesis and promote granulocyte migration. J. Allergy Clin. Immunol. 2010, 126, 1032-1040, 1040.e1-1040.e4. [CrossRef] [PubMed] 
92. Barry, O.P.; Pratico, D.; Lawson, J.A.; FitzGerald, G.A. Transcellular activation of platelets and endothelial cells by bioactive lipids in platelet microparticles. J. Clin. Investig. 1997, 99, 2118-2127. [CrossRef] [PubMed]

93. Kuravi, S.J.; Harrison, P.; Rainger, G.E.; Nash, G.B. Ability of Platelet-Derived Extracellular Vesicles to Promote Neutrophil-Endothelial Cell Interactions. Inflammation 2019, 42, 290-305. [CrossRef] [PubMed]

94. Rossaint, J.; Kühne, K.; Skupski, J.; Van Aken, H.; Looney, M.R.; Hidalgo, A.; Zarbock, A. Directed transport of neutrophil-derived extracellular vesicles enables platelet-mediated innate immune response. Nat. Commun. 2016, 7, 13464. [CrossRef] [PubMed]

95. Mazzeo, C.; Cañas, J.A.; Zafra, M.P.; Rojas Marco, A.; Fernández-Nieto, M.; Sanz, V.; Mittelbrunn, M.; Izquierdo, M.; Baixaulli, F.; Sastre, J.; et al. Exosome secretion by eosinophils: A possible role in asthma pathogenesis. J. Allergy Clin. Immunol. 2015, 135, 1603-1613. [CrossRef] [PubMed]

96. Cañas, J.A.; Sastre, B.; Mazzeo, C.; Fernández-Nieto, M.; Rodrigo-Muñoz, J.M.; González-Guerra, A.; Izquierdo, M.; Barranco, P.; Quirce, S.; Sastre, J.; et al. Exosomes from eosinophils autoregulate and promote eosinophil functions. J. Leukoc. Biol. 2017, 101, 1191-1199. [CrossRef] [PubMed]

97. Cañas, J.A.; Sastre, B.; Rodrigo-Muñoz, J.M.; Fernández-Nieto, M.; Barranco, P.; Quirce, S.; Sastre, J.; Del Pozo, V. Eosinophil-derived exosomes contribute to asthma remodelling by activating structural lung cells. Clin. Exp. Allergy 2018, 48, 1173-1185. [CrossRef]

98. Vargas, A.; Roux-Dalvai, F.; Droit, A.; Lavoie, J.P. Neutrophil-Derived Exosomes: A New Mechanism Contributing to Airway Smooth Muscle Remodeling. Am. J. Respir. Cell Mol. Biol. 2016, 55, 450-461. [CrossRef]

99. Majumdar, R.; Tavakoli Tameh, A.; Parent, C.A. Exosomes Mediate LTB4 Release during Neutrophil Chemotaxis. PLoS Biol. 2016, 14, e1002336. [CrossRef]

100. Lukic, A.; Ji, J.; Idborg, H.; Samuelsson, B.; Palmberg, L.; Gabrielsson, S.; Rådmark, O. Pulmonary epithelial cancer cells and their exosomes metabolize myeloid cell-derived leukotriene C4 to leukotriene D4. J. Lipid Res. 2016, 57, 1659-1669. [CrossRef]

101. Skotland, T.; Sandvig, K.; Llorente, A. Lipids in exosomes: Current knowledge and the way forward. Prog. Lipid Res. 2017, 66, 30-41. [CrossRef]

102. Török, N.J. Extracellular vesicles and ceramide: New mediators for macrophage chemotaxis? J. Lipid Res. 2016, 57, 157-158. [CrossRef]

103. Kakazu, E.; Mauer, A.S.; Yin, M.; Malhi, H. Hepatocytes release ceramide-enriched pro-inflammatory extracellular vesicles in an IRE1 $\alpha$-dependent manner. J. Lipid Res. 2016, 57, 233-245. [CrossRef] [PubMed]

104. Podbielska, M.; Szulc, Z.M.; Kurowska, E.; Hogan, E.L.; Bielawski, J.; Bielawska, A.; Bhat, N.R. Cytokine-induced release of ceramide-enriched exosomes as a mediator of cell death signaling in an oligodendroglioma cell line. J. Lipid Res. 2016, 57, 2028-2039. [CrossRef]

105. Park, J.A.; Sharif, A.S.; Tschumperlin, D.J.; Lau, L.; Limbrey, R.; Howarth, P.; Drazen, J.M. Tissue factor-bearing exosome secretion from human mechanically stimulated bronchial epithelial cells in vitro and in vivo. $J$. Allergy Clin. Immunol. 2012, 130, 1375-1383. [CrossRef]

106. Baranova, I.N.; Kurlander, R.; Bocharov, A.V.; Vishnyakova, T.G.; Chen, Z.; Remaley, A.T.; Csako, G.; Patterson, A.P.; Eggerman, T.L. Role of human CD36 in bacterial recognition, phagocytosis, and pathogen-induced JNK-mediated signaling. J. Immunol. 2008, 181, 7147-7156. [CrossRef] [PubMed]

107. Nazimek, K.; Bryniarski, K.; Askenase, P.W. Functions of Exosomes and Microbial Extracellular Vesicles in Allergy and Contact and Delayed-Type Hypersensitivity. Int. Arch. Allergy Immunol. 2016, 171, 1-26. [CrossRef]

108. Hong, S.W.; Kim, M.R.; Lee, E.Y.; Kim, J.H.; Kim, Y.S.; Jeon, S.G.; Yang, J.M.; Lee, B.J.; Pyun, B.Y.; Gho, Y.S.; et al. Extracellular vesicles derived from Staphylococcus aureus induce atopic dermatitis-like skin inflammation. Allergy 2011, 66, 351-359. [CrossRef]

109. Gehrmann, U.; Qazi, K.R.; Johansson, C.; Hultenby, K.; Karlsson, M.; Lundeberg, L.; Gabrielsson, S.; Scheynius, A. Nanovesicles from Malassezia sympodialis and host exosomes induce cytokine responses-novel mechanisms for host-microbe interactions in atopic eczema. PLoS ONE 2011, 6, e21480. [CrossRef]

110. Colombo, M.; Moita, C.; van Niel, G.; Kowal, J.; Vigneron, J.; Benaroch, P.; Manel, N.; Moita, L.F.; Théry, C.; Raposo, G. Analysis of ESCRT functions in exosome biogenesis, composition and secretion highlights the heterogeneity of extracellular vesicles. J. Cell Sci. 2013, 126, 5553-5565. [CrossRef]

111. Kosaka, N.; Yoshioka, Y.; Hagiwara, K.; Tominaga, N.; Katsuda, T.; Ochiya, T. Trash or Treasure: Extracellular microRNAs and cell-to-cell communication. Front. Genet. 2013, 4, 173. [CrossRef] 
112. Valencia-Sanchez, M.A.; Liu, J.; Hannon, G.J.; Parker, R. Control of translation and mRNA degradation by miRNAs and siRNAs. Genes Dev. 2006, 20, 515-524. [CrossRef]

113. Fabian, M.R.; Sonenberg, N.; Filipowicz, W. Regulation of mRNA translation and stability by microRNAs. Annu. Rev. Biochem. 2010, 79, 351-379. [CrossRef]

114. Huntzinger, E.; Izaurralde, E. Gene silencing by microRNAs: Contributions of translational repression and mRNA decay. Nat. Rev. Genet. 2011, 12,99-110. [CrossRef]

115. Maes, T.; Cobos, F.A.; Schleich, F.; Sorbello, V.; Henket, M.; De Preter, K.; Bracke, K.R.; Conickx, G.; Mesnil, C.; Vandesompele, J.; et al. Asthma inflammatory phenotypes show differential microRNA expression in sputum. J. Allergy Clin. Immunol. 2016, 137, 1433-1446. [CrossRef]

116. Seumois, G.; Vijayanand, P.; Eisley, C.J.; Omran, N.; Kalinke, L.; North, M.; Ganesan, A.P.; Simpson, L.J.; Hunkapiller, N.; Moltzahn, F.; et al. An integrated nano-scale approach to profile miRNAs in limited clinical samples. Am. J. Clin. Exp. Immunol 2012, 1, 70-89.

117. Qiao, Y.; Liang, X.; Yan, Y.; Lu, Y.; Zhang, D.; Yao, W.; Wu, W.; Yan, Z. Identification of Exosomal miRNAs in Rats with Pulmonary Neutrophilic Inflammation Induced by Zinc Oxide Nanoparticles. Front. Physiol. 2018, 9, 217. [CrossRef]

118. Rodriguez, A.; Vigorito, E.; Clare, S.; Warren, M.V.; Couttet, P.; Soond, D.R.; van Dongen, S.; Grocock, R.J.; Das, P.P.; Miska, E.A.; et al. Requirement of bic/microRNA-155 for normal immune function. Science 2007, 316, 608-611. [CrossRef]

119. Malmhäll, C.; Alawieh, S.; Lu, Y.; Sjöstrand, M.; Bossios, A.; Eldh, M.; Rådinger, M. MicroRNA-155 is essential for $\mathrm{T}(\mathrm{H}) 2$-mediated allergen-induced eosinophilic inflammation in the lung. J. Allergy Clin. Immunol. 2014, 133, 1429-1438. [CrossRef]

120. Mattes, J.; Collison, A.; Plank, M.; Phipps, S.; Foster, P.S. Antagonism of microRNA-126 suppresses the effector function of TH2 cells and the development of allergic airways disease. Proc. Natl. Acad. Sci. USA 2009, 106, 18704-18709. [CrossRef]

121. Collison, A.; Herbert, C.; Siegle, J.S.; Mattes, J.; Foster, P.S.; Kumar, R.K. Altered expression of microRNA in the airway wall in chronic asthma: miR-126 as a potential therapeutic target. BMC Pulm. Med. 2011, 11, 29. [CrossRef]

122. Pua, H.H.; Steiner, D.F.; Patel, S.; Gonzalez, J.R.; Ortiz-Carpena, J.F.; Kageyama, R.; Chiou, N.T.; Gallman, A.; de Kouchkovsky, D.; Jeker, L.T.; et al. MicroRNAs 24 and 27 Suppress Allergic Inflammation and Target a Network of Regulators of T Helper 2 Cell-Associated Cytokine Production. Immunity 2016, 44, 821-832. [CrossRef]

123. Murugaiyan, G.; da Cunha, A.P.; Ajay, A.K.; Joller, N.; Garo, L.P.; Kumaradevan, S.; Yosef, N.; Vaidya, V.S.; Weiner, H.L. MicroRNA-21 promotes Th17 differentiation and mediates experimental autoimmune encephalomyelitis. J. Clin. Investig. 2015, 125, 1069-1080. [CrossRef]

124. Mayoral, R.J.; Deho, L.; Rusca, N.; Bartonicek, N.; Saini, H.K.; Enright, A.J.; Monticelli, S. MiR-221 influences effector functions and actin cytoskeleton in mast cells. PLOS ONE 2011, 6, e26133. [CrossRef]

125. Qin, H.B.; Xu, B.; Mei, J.J.; Li, D.; Liu, J.J.; Zhao, D.Y.; Liu, F. Inhibition of miRNA-221 suppresses the airway inflammation in asthma. Inflammation 2012, 35, 1595-1599. [CrossRef]

126. Chiba, Y.; Misawa, M. MicroRNAs and their therapeutic potential for human diseases: MiR-133a and bronchial smooth muscle hyperresponsiveness in asthma. J. Pharmacol. Sci. 2010, 114, 264-268. [CrossRef]

127. Phinney, D.G.; Di Giuseppe, M.; Njah, J.; Sala, E.; Shiva, S.; St Croix, C.M.; Stolz, D.B.; Watkins, S.C.; Di, Y.P.; Leikauf, G.D.; et al. Mesenchymal stem cells use extracellular vesicles to outsource mitophagy and shuttle microRNAs. Nat. Commun. 2015, 6, 8472. [CrossRef]

128. Morrison, T.J.; Jackson, M.V.; Cunningham, E.K.; Kissenpfennig, A.; McAuley, D.F.; O’Kane, C.M.; Krasnodembskaya, A.D. Mesenchymal Stromal Cells Modulate Macrophages in Clinically Relevant Lung Injury Models by Extracellular Vesicle Mitochondrial Transfer. Am. J. Respir. Crit. Care. Med. 2017, 196, 1275-1286. [CrossRef]

129. Hough, K.P.; Trevor, J.L.; Strenkowski, J.G.; Wang, Y.; Chacko, B.K.; Tousif, S.; Chanda, D.; Steele, C.; Antony, V.B.; Dokland, T.; et al. Exosomal transfer of mitochondria from airway myeloid-derived regulatory cells to T cells. Redox Biol. 2018, 18, 54-64. [CrossRef]

130. Chalfant, C.E.; Spiegel, S. Sphingosine 1-phosphate and ceramide 1-phosphate: Expanding roles in cell signaling. J. Cell Sci. 2005, 118, 4605-4612. [CrossRef] 
131. Li, X.; Howard, T.D.; Zheng, S.L.; Haselkorn, T.; Peters, S.P.; Meyers, D.A.; Bleecker, E.R. Genome-wide association study of asthma identifies RAD50-IL13 and HLA-DR/DQ regions. J. Allergy Clin. Immunol. 2010, 125, 328-335.e311. [CrossRef]

132. Vignola, A.M.; Campbell, A.M.; Chanez, P.; Bousquet, J.; Paul-Lacoste, P.; Michel, F.B.; Godard, P. HLA-DR and ICAM-1 expression on bronchial epithelial cells in asthma and chronic bronchitis. Am. Rev. Respir. Dis. 1993, 148, 689-694. [CrossRef]

133. Théry, C.; Amigorena, S.; Raposo, G.; Clayton, A. Isolation and characterization of exosomes from cell culture supernatants and biological fluids. Curr. Protoc. Cell Biol. 2006, 30, 3-22. [CrossRef]

134. Lane, R.E.; Korbie, D.; Anderson, W.; Vaidyanathan, R.; Trau, M. Analysis of exosome purification methods using a model liposome system and tunable-resistive pulse sensing. Sci. Rep. 2015, 5, 7639. [CrossRef]

135. Escola, J.M.; Kleijmeer, M.J.; Stoorvogel, W.; Griffith, J.M.; Yoshie, O.; Geuze, H.J. Selective enrichment of tetraspan proteins on the internal vesicles of multivesicular endosomes and on exosomes secreted by human B-lymphocytes. J. Biol. Chem. 1998, 273, 20121-20127. [CrossRef]

136. Théry, C.; Boussac, M.; Véron, P.; Ricciardi-Castagnoli, P.; Raposo, G.; Garin, J.; Amigorena, S. Proteomic analysis of dendritic cell-derived exosomes: A secreted subcellular compartment distinct from apoptotic vesicles. J. Immunol. 2001, 166, 7309-7318. [CrossRef]

137. Keerthikumar, S.; Chisanga, D.; Ariyaratne, D.; Al Saffar, H.; Anand, S.; Zhao, K.; Samuel, M.; Pathan, M.; Jois, M.; Chilamkurti, N.; et al. ExoCarta: A Web-Based Compendium of Exosomal Cargo. J. Mol. Biol. 2016, 428, 688-692. [CrossRef]

138. French, K.C.; Antonyak, M.A.; Cerione, R.A. Extracellular vesicle docking at the cellular port: Extracellular vesicle binding and uptake. Semin. Cell Dev. Biol. 2017, 67, 48-55. [CrossRef]

139. Andreu, Z.; Yáñez-Mó, M. Tetraspanins in extracellular vesicle formation and function. Front. Immunol. 2014, 5, 442. [CrossRef]

140. Sinha, A.; Yadav, A.K.; Chakraborty, S.; Kabra, S.K.; Lodha, R.; Kumar, M.; Kulshreshtha, A.; Sethi, T.; Pandey, R.; Malik, G.; et al. Exosome-enclosed microRNAs in exhaled breath hold potential for biomarker discovery in patients with pulmonary diseases. J. Allergy Clin. Immunol. 2013, 132, 219-222. [CrossRef]

141. Pinkerton, M.; Chinchilli, V.; Banta, E.; Craig, T.; August, A.; Bascom, R.; Cantorna, M.; Harvill, E.; Ishmael, F.T. Differential expression of microRNAs in exhaled breath condensates of patients with asthma, patients with chronic obstructive pulmonary disease, and healthy adults. J. Allergy Clin. Immunol. 2013, 132, 217-219. [CrossRef]

142. Weiland, M.; Gao, X.H.; Zhou, L.; Mi, Q.S. Small RNAs have a large impact: Circulating microRNAs as biomarkers for human diseases. RNA Biol. 2012, 9, 850-859. [CrossRef]

143. Chairoungdua, A.; Smith, D.L.; Pochard, P.; Hull, M.; Caplan, M.J. Exosome release of $\beta$-catenin: A novel mechanism that antagonizes Wnt signaling. J. Cell Biol. 2010, 190, 1079-1091. [CrossRef]

144. Charrier, A.; Chen, R.; Chen, L.; Kemper, S.; Hattori, T.; Takigawa, M.; Brigstock, D.R. Exosomes mediate intercellular transfer of pro-fibrogenic connective tissue growth factor (CCN2) between hepatic stellate cells, the principal fibrotic cells in the liver. Surgery 2014, 156, 548-555. [CrossRef]

145. Chen, L.; Charrier, A.; Zhou, Y.; Chen, R.; Yu, B.; Agarwal, K.; Tsukamoto, H.; Lee, L.J.; Paulaitis, M.E.; Brigstock, D.R. Epigenetic regulation of connective tissue growth factor by MicroRNA-214 delivery in exosomes from mouse or human hepatic stellate cells. Hepatology 2014, 59, 1118-1129. [CrossRef]

146. Dinkins, M.B.; Dasgupta, S.; Wang, G.; Zhu, G.; Bieberich, E. Exosome reduction in vivo is associated with lower amyloid plaque load in the 5XFAD mouse model of Alzheimer's disease. Neurobiol. Aging 2014, 35, 1792-1800. [CrossRef]

147. Guo, B.B.; Bellingham, S.A.; Hill, A.F. The neutral sphingomyelinase pathway regulates packaging of the prion protein into exosomes. J. Biol. Chem. 2015, 290, 3455-3467. [CrossRef]

148. Ohshima, K.; Kanto, K.; Hatakeyama, K.; Ide, T.; Wakabayashi-Nakao, K.; Watanabe, Y.; Sakura, N.; Terashima, M.; Yamaguchi, K.; Mochizuki, T. Exosome-mediated extracellular release of polyadenylate-binding protein 1 in human metastatic duodenal cancer cells. Proteomics 2014, 14, 2297-2306. [CrossRef]

149. Wang, X.; Huang, W.; Liu, G.; Cai, W.; Millard, R.W.; Wang, Y.; Chang, J.; Peng, T.; Fan, G.C. Cardiomyocytes mediate anti-angiogenesis in type 2 diabetic rats through the exosomal transfer of miR-320 into endothelial cells. J. Mol. Cell Cardiol. 2014, 74, 139-150. [CrossRef] 
150. Luberto, C.; Hassler, D.F.; Signorelli, P.; Okamoto, Y.; Sawai, H.; Boros, E.; Hazen-Martin, D.J.; Obeid, L.M.; Hannun, Y.A.; Smith, G.K. Inhibition of tumor necrosis factor-induced cell death in MCF7 by a novel inhibitor of neutral sphingomyelinase. J. Biol. Chem. 2002, 277, 41128-41139. [CrossRef]

151. Cogolludo, A.; Moreno, L.; Frazziano, G.; Moral-Sanz, J.; Menendez, C.; Castañeda, J.; González, C.; Villamor, E.; Perez-Vizcaino, F. Activation of neutral sphingomyelinase is involved in acute hypoxic pulmonary vasoconstriction. Cardiovasc. Res. 2009, 82, 296-302. [CrossRef]

152. Walton, K.A.; Gugiu, B.G.; Thomas, M.; Basseri, R.J.; Eliav, D.R.; Salomon, R.G.; Berliner, J.A. A role for neutral sphingomyelinase activation in the inhibition of LPS action by phospholipid oxidation products. J. Lipid Res. 2006, 47, 1967-1974. [CrossRef]

153. Gon, Y.; Maruoka, S.; Inoue, T.; Kuroda, K.; Yamagishi, K.; Kozu, Y.; Shikano, S.; Soda, K.; Lötvall, J.; Hashimoto, S. Selective release of miRNAs via extracellular vesicles is associated with house-dust mite allergen-induced airway inflammation. Clin. Exp. Allergy 2017, 47, 1586-1598. [CrossRef]

154. Cruz, F.F.; Borg, Z.D.; Goodwin, M.; Sokocevic, D.; Wagner, D.E.; Coffey, A.; Antunes, M.; Robinson, K.L.; Mitsialis, S.A.; Kourembanas, S.; et al. Systemic Administration of Human Bone Marrow-Derived Mesenchymal Stromal Cell Extracellular Vesicles Ameliorates Aspergillus Hyphal Extract-Induced Allergic Airway Inflammation in Immunocompetent Mice. Stem Cells Transl. Med. 2015, 4, 1302-1316. [CrossRef]

155. Du, Y.M.; Zhuansun, Y.X.; Chen, R.; Lin, L.; Lin, Y.; Li, J.G. Mesenchymal stem cell exosomes promote immunosuppression of regulatory $\mathrm{T}$ cells in asthma. Exp. Cell Res. 2018, 363, 114-120. [CrossRef]

156. Lai, Y.; Long, Y.; Lei, Y.; Deng, X.; He, B.; Sheng, M.; Li, M.; Gu, Z. A novel micelle of coumarin derivative monoend-functionalized PEG for anti-tumor drug delivery: In vitro and in vivo study. J. Drug Target 2012, 20, 246-254. [CrossRef]

157. Raimondo, S.; Giavaresi, G.; Lorico, A.; Alessandro, R. Extracellular Vesicles as Biological Shuttles for Targeted Therapies. Int. J. Mol. Sci. 2019, 20. [CrossRef]

158. Laulagnier, K.; Motta, C.; Hamdi, S.; Roy, S.; Fauvelle, F.; Pageaux, J.F.; Kobayashi, T.; Salles, J.P.; Perret, B.; Bonnerot, C.; et al. Mast cell- and dendritic cell-derived exosomes display a specific lipid composition and an unusual membrane organization. Biochem. J. 2004, 380, 161-171. [CrossRef]

159. Clayton, A.; Harris, C.L.; Court, J.; Mason, M.D.; Morgan, B.P. Antigen-presenting cell exosomes are protected from complement-mediated lysis by expression of CD55 and CD59. Eur. J. Immunol. 2003, 33, 522-531. [CrossRef]

160. Sun, D.; Zhuang, X.; Xiang, X.; Liu, Y.; Zhang, S.; Liu, C.; Barnes, S.; Grizzle, W.; Miller, D.; Zhang, H.G. A novel nanoparticle drug delivery system: The anti-inflammatory activity of curcumin is enhanced when encapsulated in exosomes. Mol. Ther. 2010, 18, 1606-1614. [CrossRef]

161. Mizrak, A.; Bolukbasi, M.F.; Ozdener, G.B.; Brenner, G.J.; Madlener, S.; Erkan, E.P.; Ströbel, T.; Breakefield, X.O.; Saydam, O. Genetically engineered microvesicles carrying suicide mRNA/protein inhibit schwannoma tumor growth. Mol. Ther. 2013, 21, 101-108. [CrossRef]

162. Tian, Y.; Li, S.; Song, J.; Ji, T.; Zhu, M.; Anderson, G.J.; Wei, J.; Nie, G. A doxorubicin delivery platform using engineered natural membrane vesicle exosomes for targeted tumor therapy. Biomaterials 2014, 35, 2383-2390. [CrossRef]

163. György, B.; Hung, M.E.; Breakefield, X.O.; Leonard, J.N. Therapeutic applications of extracellular vesicles: Clinical promise and open questions. Annu. Rev. Pharmacol. Toxicol. 2015, 55, 439-464. [CrossRef]

164. Kooijmans, S.A.A.; Stremersch, S.; Braeckmans, K.; de Smedt, S.C.; Hendrix, A.; Wood, M.J.A.; Schiffelers, R.M.; Raemdonck, K.; Vader, P. Electroporation-induced siRNA precipitation obscures the efficiency of siRNA loading into extracellular vesicles. J. Control. Release 2013, 172, 229-238. [CrossRef]

165. Hood, J.L.; Scott, M.J.; Wickline, S.A. Maximizing exosome colloidal stability following electroporation. Anal. Biochem. 2014, 448, 41-49. [CrossRef]

166. Cañas, J.A.; Sastre, B.; Rodrigo-Muñoz, J.M.; Del Pozo, V. Exosomes: A new approach to asthma pathology. Clin. Chim. Acta. 2019, 495, 139-147. [CrossRef]

167. Bianco, N.R.; Kim, S.H.; Ruffner, M.A.; Robbins, P.D. Therapeutic effect of exosomes from indoleamine 2,3-dioxygenase-positive dendritic cells in collagen-induced arthritis and delayed-type hypersensitivity disease models. Arthritis Rheum. 2009, 60, 380-389. [CrossRef]

168. Zhang, Y.; Chopp, M.; Meng, Y.; Katakowski, M.; Xin, H.; Mahmood, A.; Xiong, Y. Effect of exosomes derived from multipluripotent mesenchymal stromal cells on functional recovery and neurovascular plasticity in rats after traumatic brain injury. J. Neurosurg. 2015, 122, 856-867. [CrossRef] 
169. Maguire, C.A.; Balaj, L.; Sivaraman, S.; Crommentuijn, M.H.; Ericsson, M.; Mincheva-Nilsson, L.; Baranov, V.; Gianni, D.; Tannous, B.A.; Sena-Esteves, M.; et al. Microvesicle-associated AAV vector as a novel gene delivery system. Mol. Ther. 2012, 20, 960-971. [CrossRef]

170. Feng, Z.; Hensley, L.; McKnight, K.L.; Hu, F.; Madden, V.; Ping, L.; Jeong, S.H.; Walker, C.; Lanford, R.E.; Lemon, S.M. A pathogenic picornavirus acquires an envelope by hijacking cellular membranes. Nature 2013, 496, 367-371. [CrossRef]

171. Livshits, M.A.; Livshts, M.A.; Khomyakova, E.; Evtushenko, E.G.; Lazarev, V.N.; Kulemin, N.A.; Semina, S.E.; Generozov, E.V.; Govorun, V.M. Isolation of exosomes by differential centrifugation: Theoretical analysis of a commonly used protocol. Sci. Rep. 2015, 5, 17319. [CrossRef]

172. Tauro, B.J.; Greening, D.W.; Mathias, R.A.; Ji, H.; Mathivanan, S.; Scott, A.M.; Simpson, R.J. Comparison of ultracentrifugation, density gradient separation, and immunoaffinity capture methods for isolating human colon cancer cell line LIM1863-derived exosomes. Methods 2012, 56, 293-304. [CrossRef]

173. Nakai, W.; Yoshida, T.; Diez, D.; Miyatake, Y.; Nishibu, T.; Imawaka, N.; Naruse, K.; Sadamura, Y.; Hanayama, R. A novel affinity-based method for the isolation of highly purified extracellular vesicles. Sci. Rep. 2016, 6, 33935. [CrossRef]

174. Oksvold, M.P.; Neurauter, A.; Pedersen, K.W. Magnetic bead-based isolation of exosomes. Methods Mol. Biol. 2015, 1218, 465-481. [CrossRef]

175. Böing, A.N.; van der Pol, E.; Grootemaat, A.E.; Coumans, F.A.; Sturk, A.; Nieuwland, R. Single-step isolation of extracellular vesicles by size-exclusion chromatography. J. Extracell Vesicles 2014, 3. [CrossRef]

176. Lobb, R.; Möller, A. Size Exclusion Chromatography: A Simple and Reliable Method for Exosome Purification. Methods Mol. Biol. 2017, 1660, 105-110. [CrossRef]

177. Gámez-Valero, A.; Monguió-Tortajada, M.; Carreras-Planella, L.; Franquesa, M.; Beyer, K.; Borràs, F.E. Size-Exclusion Chromatography-based isolation minimally alters Extracellular Vesicles' characteristics compared to precipitating agents. Sci. Rep. 2016, 6, 33641. [CrossRef]

178. Xu, R.; Simpson, R.J.; Greening, D.W. A Protocol for Isolation and Proteomic Characterization of Distinct Extracellular Vesicle Subtypes by Sequential Centrifugal Ultrafiltration. Methods Mol. Biol. 2017, 1545, 91-116. [CrossRef]

179. He, L.; Zhu, D.; Wang, J.; Wu, X. A highly efficient method for isolating urinary exosomes. Int. J. Mol. Med. 2019, 43, 83-90. [CrossRef]

180. Oeyen, E.; Van Mol, K.; Baggerman, G.; Willems, H.; Boonen, K.; Rolfo, C.; Pauwels, P.; Jacobs, A.; Schildermans, K.; Cho, W.C.; et al. Ultrafiltration and size exclusion chromatography combined with asymmetrical-flow field-flow fractionation for the isolation and characterisation of extracellular vesicles from urine. J. Extracell Vesicles 2018, 7, 1490143. [CrossRef]

(C) 2019 by the authors. Licensee MDPI, Basel, Switzerland. This article is an open access article distributed under the terms and conditions of the Creative Commons Attribution (CC BY) license (http://creativecommons.org/licenses/by/4.0/). 